\title{
PELATIHAN PEMBUATAN VIDEO PEMBELAJARAN DI TK. AL-JABBAR BLIMBING KOTA MALANG
}

\author{
Ahmad Fauzi $^{1)}$, Eko Boedi Santoso ${ }^{2)}$, Ayu Sulasari ${ }^{3)}$, Kartika Indah $^{4)}$, Fahmi Muhammad ${ }^{5)}$ \\ Jurusan Administrasi Niaga Politeknik Negeri Malang \\ fauzipoltek@gmail.com ${ }^{1)}$
}

\begin{abstract}
Abstrak - The targets of community service activities are the teachers or educators of Malang City's AlJabbar Kindergarten (TK), and other private kindergartens around them. The selection of private Al-Jabbar Kindergarten teachers is because the existing facilities of the school are inadequate, so there is a need for learning media assistance and enhancement of the quality of creative teachers in the learning process. This activity aims to help improve the quality of the learning process by increasing the ability of teachers in this school, so that learning is better and more enjoyable. PKM activities include: Introductory material, Learning media demo, Provision of Materials, practical training in making instructional media, Planning learning media according to topic, making instructional media according to plan, discussion and evaluation of learning media and finally improvement in making instructional media..
\end{abstract}

Kata kunci: learning, video, media, teacher

\section{PENDAHULUAN}

\subsection{Latar Belakang}

TK/RA Al-Jabbar Blimbing Kota Malang terus ingin meningkatkan kualitas lulusannya lewat kualitas proses pembelajarannya dan kualitas gurunya. Sekolah Taman Kanak-kanak yang dipimpin oleh Husnul Khotimah, S.Ag sudah memiliki komputer sebagai media pembelajaran (Laboratorium Komputer) dan juga perangkat LCD, namun sampai saat ini belum diberdayakan secara maksimal, hal ini dikarenakan mayoritas guru belum memiliki ketrampilan yang maksimal sehingga komputer, televisi, LCD, dan perangkat elektronik yang lain tidak bisa diberdayakan secara baik untuk pembelajaran, sehingga proses pembelajaran kurang maksimal, selain material pembelajaran atau software yang digunakan untuk pembelajaran juga belum tersedia.

TK/RA Al-Jabbar Blimbing Kota Malang dilihat dari faktor sosial georafis sangat strategis karena berada ditengah kota Malang dasamping pemukiman yang sangat padat, sehingga siswa yang sekolah di TK ini cukup banyak, walau dari kalangan menengah kebawah dengan cukup berjalan kaki. Kelebihan yang dimiliki oleh sekolah ini adalah sekolah yang bernafaskan keislaman, sehingga bagi orang tua menjadi pertimbangan tersendiri untuk menyekolahkan anaknya di sekoah ini, selain itu tempatnya sangat mudah diakses. Kekurangan dari sekolah ini adalah Sumber daya manusianya sangat terbatas baik dari jumlah pengajarnya maupun kemampuan pengajarannya, khususnya terkait dengan penggunaan media pembelajaran berbasis audio visual.

Berdasar hal tersebut di atas maka lewat program pengabdian pada masyarakat Politeknik Negeri Malang diperlukan pelatihan pembuatan video pembelajaran dengan aplikasi sony vegas di TK/RA Al-Jabbar Blimbing Kota Malang. Dengan harapan dapat membantu meningkatkan sumber daya manusianya, khususnya guru-gurunya dan pada akhirnya dapat dimanfaatkan untuk anak didiknya

\section{KAJIAN LITERATUR}

\subsection{Pengertian E-learning}

Internet, Intranet, satelit, tape audio/video, TV interaktif dan CD-ROM adalah sebahagian dari media elektronik yang digunakan Pengajaran boleh disampaikan secara 'synchronously' (pada waktu yang sama) ataupun 'asynchronously' (pada waktu yang berbeda). Materi pengajaran dan pembelajaran yang disampaikan melalui media ini mempunyai teks, grafik, animasi, simulasi, audio dan video. Ia juga harus menyediakan kemudahan untuk 'discussion group' dengan bantuan profesional dalam bidangnya.

Khoe-Yao-Tung (2000) mengatakan bahwa setelah kehadiran guru dalam arti sebenarnya, internet akan menjadi suplemen dan komplemen dalam menjadikan wakil guru yang mewakili sumber belajar yang penting di dunia. Dalam hal ini Cisco (2001) menjelaskan filosofis e-learning sebagai berikut: elearning merupakan penyampian informasi, komunikasi, pendidikan, pelatihan secara on-line. elearning menyediakan seperangkat alat yang dapat memperkaya nilai belajar secara konvensional (model belajar konvensional, kajian terhadap buku teks, CDROM, dan pelatihan berbasis komputer) sehingga dapat menjawab tantangan perkembangan globalisasi. e-learning tidak berarti menggantikan model belajar konvensional di dalam kelas, tetapi memperkuat model belajar tersebut melalui pengayaan content dan pengembangan teknologi pendidikan.

\subsection{Tekonologi Pendukung Elearning}

Dalam prakteknya e-learning memerlukan bantuan teknologi. Karena itudikenal istilah:

- computer based learning (CBL) yaitu pembelajaran yang sepenuhnya menggunakan komputer;

- computer assisted learning (CAL) yaitu pembelajaran yang menggunakan alat bantu utama komputer.

Technology based learning ini pada prinsipnya terdiri dari Audio Information Technologies (radio, 
audio tape, voice mail telephone) dan Video Information Technologies (video tape, video text, video messaging). Sedangkan technology based weblearning pada dasarnya adalah Data Information Technologies (bulletin board, Internet, e-mail, telecollaboration). Dalam pelaksanaan pembelajaran sehari-hari, yang sering dijumpai adalah kombinasi dari teknologi yang dituliskan di atas (audio/data, video/data, audio/video). Teknologi ini juga sering di pakai pada pendidikan jarak jauh (distance education), dimasudkan agar komunikasi antara murid dan guru bisa terjadi dengan keunggulan teknologi e-learning ini.

E-learning bersifat jaringan, yang membuatnya mampu memperbaiki secara cepat, menyimpan atau memunculkan kembali, mendistribusikan, dan sharing pembelajaran dan informasi. Persyaratan ini sangatlah penting dalam e-learning, sehingga Rosenberg menyebutnya sebagai persyaratan absolut. e-learning dikirimkan kepada pengguna melalui komputer dengan menggunakan standar teknologi internet. CD ROM, Web TV, Web Cell Phones, pagers, dan alat bantu digital personal lainnya walaupun bisa menyiapkan pesan pembelajaran tetapi tidak bisa digolongkan sebagai e-learning. e-learning terfokus pada pandangan pembelajaran yang paling luas, solusi pembelajaran yang menggungguli paradikma tradisional dalam pelatihan. Sebalikanya Computer assisted learning (CAL) menggunakan alat bantu utama komputer, karna hanya bisa dijalankan lewat komputer, sering disebut juga pembelajaran multimedia interaktif

\subsection{Pengembangan Model Pembelajaran}

Pendapat Haughey (1998) tentang pengembangan e-learning. Menurutnya adatiga kemungkinan dalam pengembangan sistem pembelajaran berbasis internet, yaitu web course, web centric course, dan web enhanced course". Web course adalah penggunaan internet untuk keperluan pendidikan, yang mana peserta didik dan pengajar sepenuhnya terpisah dan tidak diperlukan adanya tatap muka. Seluruh bahan ajar, diskusi, konsultasi, penugasan, latihan, ujian, dan kegiatan pembelajaran lainnya sepenuhnya disampaikan melalui internet. Dengan kata lain model ini menggunakan sistem jarak jauh.

Faktor Yang Dipertimbangkan Sebelum Memanfaatkan E-Learning Ahli-ahli pendidikan dan internet menyarankan beberapa hal yang perlu diperhatikan sebelum seseorang memilih internet untuk kegiatan pembelajaran, antara lain:

- Analisis Kebutuhan (Need Analysis)

- Rancangan Instruksional

- Tahap Pengembangan

- Pelaksanaan

- Evaluasi

\subsection{Multimedia}

Multimedia adalah penggunaan komputer untuk menyajikan dan menggabungkan teks, suara gambar, animasi dan video dengan alat bantu (tool) dan koneksi (link) sehingga pengguna dapat bernavigasi, berinteraksi dan berkomunikasi. Multimedia banyak digunakan dalam dunia hiburan. Multimedia dimanfaatkan juga dalam dunia bisnis, multimedia digunakan sebagai media profil perusahaan, bahkan sebagai media pelatihan dalam sistem e-learning.

\subsection{Unsur - Unsur Multimedia}

1. Teks

Teks adalah kombinasi huruf yang membentuk satu perkataan yang menerangkan suatu topik dan topik ini dikenal dengan informasi berteks.

2. Citra atau image

Citra atau image juga mendukung pemahaman seseorang terhadap suatu informasi. Citra bersifat statis, jadi informasi yang akan disampaikan kepada pemirsa akan lebih mudah dipahami.

3. Gerakan atau animasi

Animasi adalah gambar yang memuat objek yang seolah-olah hidup, disebabkan oleh kumpulan gambar yang ditampilkan secara bergantian.

4. Suara

Suara dalam arti subjektif digunakan untuk melukiskan kesadaran seseorang bila ujung syaraf pendengarannya mendapat rangsangan. Dan dalam arti objektif digunakan sehubungan dengan timbulnya gelombang kompresi dalam udara yang dapat merangsang syaraf pendengaran.

5. Video

Video adalah media digital yang menunjukkan susunan atau urutan gambargambar dan memberikan ilusi, gambaran serta fantasi kepada gambar yang bergerak. (Erlin Andriana, 2013)

\subsection{Memproduksi Multimedia}

Terdapat tiga tahapan dalam memproduksi sistem multimedia komersial, misalnya iklan televisi, profil perusahaan, atau situs web perusahaan, yaitu praproduksi, produksi, dan pasca produksi. (Suyanto, 2004: 201)

- Tahap Pra-Produksi

Merupakan tahap semua pekerjaan dan aktivitas yang terjadi sebelum multimedia komersial diproduksi secara nyata. Perencanaan secara baik sebelum diproduksi. Pertama-tama yang harus dipkirkan pada tahap ini adalah mempelajari naskah, storyboard, dan menganalisis teknik produksi.

\section{- Produksi}

Periode selama iklan televisi diproduksi secara komersial. Tahap ini meliputi kegiatan syuting, perekaman suara, pengaturan pencahayaan, dan pemilihan kamera.

- Pasca Produksi

Periode di mana semua pekerjaan dan aktivitas yang terjadi setelah iklan televisi diproduksi secara nyata untuk keperluan komersil. Kegiatan Pasca Produksi meliputi pengeditan, pemberian efek- efek special, perekaman efek suara, pencampuran audio dan video, penggandaan serta penyiaran.

\subsection{Sony Vegas Pro}

Yopie Nugraha (2011:43) menjelaskan bahwa Sony Vegas Pro merupakan salah satu software yang terbaik dalam proses editing. Sony Vegas Pro adalah 
perangkat editor multimedia yang sukses bersaing dengan nama besar di bidang editing video. Sony Vegas Pro memiliki interface untuk editing lebih persisi dan mudah. Sony Vegas Pro memiliki interface pada panel langsung tampak dilayar dan fitur Drag and Drop. Drag and drop dilakukan tanpa harus menyelurusi file untuk menyisipkan file gambar atau video ke dalam Sony Vegas Pro.

\section{METODE}

\subsection{Sasaran}

Dalam kegiatan pengabdian kepada masyarakat ini yang menjadi sasaran adalah guru-guru atau tenaga pendidik Taman Kanak-kanak Al-Jabbar Kota Malang, dan sekolah TK swasta lainnya yang ada di kota Malang.

Mengapa kami memilih TK swasta karna sangat jarang mendapat bantuan fasilitas dan pengembangan Sumber Daya Manusianya. Sehingga dengan adanya kegiatan dapat menjadikan sekolah lebih baik, khususnya Taman Kanak-kanak Swasta.

\subsection{Metode PKM}

Metode yang digunakan dalam Pengabdian Kepada Kepada Masyarakat ini dalam bentuk pelatihan/workshop, pembimbingan dan pendampingan mulai memberi wawasan tentang pembelajaran elearning, membuat media pembelajaran audio visual, dan memanfaatkan media pemebelajaran yang telah dibuat, tahapan proses yang dilakukan adalah sebagai berikut:

- Pengantar Materi

- Demo Video Pembelajaran

- Penyampaiaan Materi Pelatihan

- Praktik sesuai Materi Ajar

- Merencakan pembelajaran sesuai topik pembelajaran

- Membuat Video Pembelajaran sesuai rencana pembuatan

- Evaluasi hasil Video pembelajaran

- Perbaikan hasil Video Pembelajaran

\section{HASIL DAN PEMBAHASAN}

\subsection{Faktor Penghambat}

Pelaksanaan kegiatan pengabdian pada masyarakat ini dirasa tidak ada faktor penghambat yang serius. Hal ini disebabkan tingkat pendidikan para peserta relative sama. Ditambah lagi, dengan adanya tanya jawab dan diskusi serta semangat dan ketekunan yang tinggi, hal ini mendukung dalam penyampaian materi berlangsung dengan lancar. Dari aspek pemateri, dengan kesabaran dan ketelatenan dalam membimbing peserta pelatihan hal ini mendukung pelaksanaan pelatihan dapat berlangsung dengan baik.

\subsection{Faktor Pendorong.}

- Pengabdian pada masyarakat ini dalam pelaksanaannya dirasakan ada beberapa faktor pendorong yang menjadikan kegiatan ini dapat dilaksanakan dengan lancar, yaitu:
- Minat dan semangat para peserta dalam mengikuti pelatihan sangat besar sekali, sehingga mempermudah dalam proses belajar mengajar dan pemberian motivasi meskipun dalam kondisi yang sederhana.

- Para peserta mempunyai tekad besar untuk mengetahui materinya sehingga dapat mendorong terlaksananya aktivitas pengabdian pada masyarakat ini.

- Pengajar yang selalu siap dengan materi dan alat bantu pengajarannya sehingga memperlancar pelaksanaan kegiatan.

\subsection{Hasil yang Diperoleh}

Hasil dari kegiatan ini adalah adanya pemahaman tentang pembelajaran berbasis Audio visual khususnya dengan sony vegas. Beberapa peserta sangat antusias mencoba mempraktekkan materi pembelajaran sesuai bidang ilmu masing-masing guru, dan mengikuti materi yang dicontohkan para pemateri.

\subsection{Evaluasi}

Setelah selesainya kegiatan pengabdian pada masyarakat maka hasilnya dapat dievaluasi sebagai berikut :

\section{- Relevansi}

Pengabdian ini diikuti dengan praktek yang mempunyai tujuan membekali ketrampilan menyiapkan materi dan menyampaiakn materi pembelajaran berbasis internet, meskipun dengan suasana nonformal, namun sangat relevan bagi peserta dalam rangka meningkatkan ilmu pengetahuan dan keterampilannya.

- Akseptabilitas

Materi yang diberikan mudah diterima dan dimengerti oleh peserta, karena materinya bersifat praktis dan bahasa yang efektif, walaupun materi yang disampaikan termasuk materi yang sangat baru bagi para peserta, khususnya pembelajaran berbasis audio visual.

- Efektifitas

Pengabdian ini efektif mencapai tujuannya terutama bagi mereka yang mempunyai daya kreativitas pembelajaran yang tinggi dan mempunyai kemam kemampuan komputer yang memadai

\section{- Ketepatan}

Ketrampilan yang diberikan sangat tepat sekali, karena akan memperkaya materi pembelajaran dan metode pembelajaran yang sangat bervariasi dan menarik siswa sehingga tidak membosankan dan berguna sebagai bekal dihari kelak untuk memperkaya pengetahuan dan memajukan pembelajaran.

- Kegunaan

Materi ini sangat berguna untuk mengantisipasi jika suatu saat guru berhalangan hadir, sehingga guru cukup memberi materi pembelajaran yang sudah tervisualisasikan dan siswa belajar mandiri.

- Pengaruh jangka panjang 
Akan membawa kemajuan metode pembelajaran di lingkungan sekolah/TK dalam rangka mensukseskan program pendidikan dan membekali pengetahuan dan ketrampilan.

- Daya ulang dan kreativitas

Upaya yang harus dilakukan untuk dapat menerapkan ketrampilan dengan lancar dan baik, harus selalu dipraktikkan agar ketrampilan yang telah diberikan tidak hilang.

\section{KESIMPULAN}

Kesimpulan yang dapat diambil berdasarkan pelaksanaan pengabdian masyarakat ini adalah sebagai berikut :

a. Pengabdian ini adalah merupakan kegiatan untuk memperoleh tambahan keterampilan dan pengetahuan serta aplikasi dalam rangka meningkatkan kemampuan mengajar yang berbasis audio visual.

b. Motivasi peserta sangat tinggi, hal ini terlihat dari antusiasnya peserta mengikuti sampai akhir program.

c. Dari hasil pengamatan selama proses kegiatan ini berlangsung maka dapat dilihat bahwa ratarata penerimaan materi yang disampaikan oleh instruktur cukup baik.

d. Untuk lebih meningkatkan ketrampilan yang telah diperoleh maka perlu kiranya para peserta untuk lebih banyak berlatih.

\section{REFERENSI}

[1]. Asep Saepudin, Penerapan Teknologi Informasi Dalam Pendidikan Masyarakat, Jurnal Teknodik, Edisi No.12/VII/Oktober/2003.

[2]. Budi Rahardjo, Proses e-Learning di Perguruan Tinggi, Seminar \& Workshop, ITB, 11 Desember 2003.

[3]. Jaya Kumar C. Koran, Aplikasi 'E-Learning' Dalam Pengajaran Dan Pembelajaran Di SekolahSekolah Malaysia: Cadangan Perlaksanaan Pada Senario Masa Kini, Pasukan Projek Rintis Sekolah Bestari Bahagian Teknologi Pendidikan, Kementerian Pendidikan Malaysia.

[4]. Mustafa, Habibi. 2011. Download Sony Vegas Pro 10 dan Keygen. (Online). (habibimustafa.wordpress.com). Diakses pada 13 April 2013 pukul 08.44 WIB.

[5]. Oos M. Anwas, Model Inovasi E-Learning Dalam Meningkatkan MutuPendidikan, Jurnal Teknodik, Edisi No.12/VII/Oktober/2003.

[6]. Romi Satria Wahono, Strategi Baru Pengelolaan Situs eLearning Gratis,

[7]. http://www.ilmukomputer.com, 2003.

[8]. Soekartawi, Prinsip Dasar E-Learning: Teori Dan Aplikasinya Di Indonesia, Jurnal Teknodik, Edisi No.12/VII/Oktober/2003.
[9]. Zanupratama, Ari. 2013. Sony Vegas. (http://arizanupratama.wordpress.com/2011/12/18/ sony-vegas/). Diakses pada 14 April 2013 pukul 07.45 WIB. 